\title{
Use of Space and the Need for Planning in the Disaster-Prone Area of Code River, Yogyakarta, Indonesia
}

\author{
Rini Rachmawati and Charina Vertinia Budiarti
}

Received: 2402 2016 / Accepted: 1107 2016 / Published online: 30122016

๑ 2016 Faculty of Geography UGM and The Indonesian Geographers Association

\begin{abstract}
The Code Riverbank is prone to flooding from lahars due to the regular eruption of Mount Merapi. The study focuses on the affected areas in Danurejan, Yogyakarta City, Indonesia. The purpose of this study is 1) to identify and analyze the use of space after the disaster, and 2) to analyze the action as well as spatial planning needs after the disaster. Data were collected from secondary and primary data. The primary data were obtained through observation, in-depth interviews, and focus group discussions. The results show that the utilization of space in the anticipation of the lahar flood disaster is still limited to the construction of an elevated levee. Research findings suggest attention should be brought to the utilization of space related to vulnerable groups. In addition, public participation, preparation of design toward ecotourism and economic value, integration of risk analysis, and spatial distribution of risk should be aggregated into a detailed spatial plan.
\end{abstract}

Keywords: Spatial Analysis, Spatial Planning, Disaster Prone Areas, Riverbank

Abstrak Tepi Sungai Code merupakan daerah rawan terhadap banjir lahar yang disebabkan oleh erupsi Gunungapi Merapi. Penelitian ini menfokuskan pada daerah terdampak di Danurejan, Kota Yogyakarta, Indonesia. Tujuan dari penelitian ini adalah 1) untuk mengidentifikasi dan menganalisa fungsi ruang setelah bencana, dan 2) untuk menganalisa tindakan perencanaan ruang yang dibutuhkan setelah bencana. Data dikumpulkan dari data sekunder dan primer. Data primer diperoleh melalui observasi, interview mendalam, dan diskusi kelompok terfokus. Hasil menunjukkan bahwa pemanfaatan ruang dalam antisipasi dari bencana banjir lahar masih terbatas untuk pembangunan peninggian tanggul. Temuan penelitian menyarankan perlunya perhatian terhadap pemanfaatan ruang untuk kelompok yang rentan. Selain itu juga perlunya partisipasi publik dalam pemanfaatan ruang, penyiapan desain ekowisata dan kegiatan bernilai ekonomi. Selan itu juga perlu adanya integrasi analisis risiko dan distribusi spasial dari risiko yang dituangkan dalam rencana rinci tata ruang.

Kata kunci : Analisis Spasial, Perencanaan Ruang, Daerah Rawan Bencana, Tepi Sungai

\section{Introduction}

Volcanic catastrophes constitute a major problem in many countries. In recent years, population growth and the expansion of settlements have greatly increased the impact of volcanic disasters [Pareschi, et al. 1999]. Volcanoes can produce a variety of phenomena that endanger the environment, people, and infrastructure. For example, Merapi eruption events have caused various effects of loss, including environmental degradation, loss of life, property, and others [Damiania, 2006; Yulianto, et al. 2012]. Merapi is the most active volcano in Indonesia and is located in the province of Central Java and Yogyakarta

Rini Rachmawati, Charina Vertinia Budiarti Department of Development Geography, Faculty of Geography, Universitas Gadjah Mada, Indonesia. Email: r_rachmawati@geo.ugm.ac.id
Special Province. Merapi erupts regularly. The impacts of the eruption events have been recorded since 1822 [Lavigne et al. 2000; 2008 in Yulianto et al. 2012]. Eruption events in 1900 destroyed five villages, killing more than 100 people and in 1920, 1932, 1961, 1996, 1973, 1974, 1975, 1976, 1994, $1995,1996,1998$, there has been more than 300 people killed and 500 houses damaged by the eruptions [Lavigne, et al. 2000, 2008 in Yulianto, et al. 2012]. Since the beginning of the 20th century, not less than 35 lahar events caused damage on the slopes of Merapi [Putra, et al., 2011]. About 200,000 people live at risk in areas prone to pyroclastic flows, and 120,000 more live in the area along the 13 rivers that are prone to lahars [Lavigne, et al., 2000 in Marfai, et al. 2008].

Lahars and pyroclastic flows are the most threatening phenomena and are difficult to cope 
with [Thouret, 1999]. In the case of Pinatubo at Philippines, local people who cannot cope alone with the long-term cost of recovery, rehabilitation, and reconstruction suffer heavily from the protracted destructions of the lahars originating from the Pinatubo [Thouret, 1999].

The 2010 eruption of Merapi that struck some parts of Sleman Regency, eventually led to the lahar flood in Sleman Regency (Jumadi et al, 2012) and the city of Yogyakarta. In general, there are three elements of infrastructure, which are potentially threatened by lahar, namely roads, bridges, settlement, and irrigation infrastructure (Jumadi et al, 2012). The settlement located along both sides of the Code River is an area prone to lahar flooding, especially the area located in the Danurejan Subdistrict. The area is vulnerable because it is heavily populated with very close proximity to the river bank. As a riparian area in general, this location belongs to the area destined for buffer protection. In the previous November 1994 eruption of Mt. Merapi, Code River, which cuts across the city of Yogyakarta, was flooded with lahar consisting of volcanic debris flow [Lavigne, 1999]. The term lahar, of Javanese origin, is a rapidly flowing mixture of rock debris and water [other than normal stream flow] from a volcano [Lavigne, 1999].

The assessment result shows that about 13,000 people live in risky areas along the river, and the estimated loss could reach up to the US\$ 52 million. However, the level of risk varies among the urban fringes [Lavigne, 1999]. The lahar flood disaster that hit the Code River banks is caused by the settlement located close to the riversides. The rapid development of settlement along the Code River that should be directed as a protected area is a proof of the weakness of spatial planning. Furthermore, the lack of infrastructure such as drainage system gives significant contribution on flood in the area [Heryanti and Kingma, 2012].

The government needs to develop a comprehensive land use plan that protects the resources of affected areas from hazards, such as volcanic eruptions [Damiani, 2006]. In this regard, Indonesia established the Spatial Planning Act. Number 26 year 2007. Based on the spatial plans of Yogyakarta City, Code River bank area should serve as a protected area. The Code River area is functioning as a protected area, meaning that the permitted activities carried out in this area are prioritized to protect the sustainability of the Code River.

Therefore, it is important to examine the uses of existing space in the study area and the spatial planning that needs to be applied in the area after the eruption of Mt. Merapi. This study aims 1) to identify and analyze the utilization of the postdisaster space, and 2) to analyze the spatial arrangement related to the post-disaster needs.

In this case study there is lack of detail spatial planning that can be used to anticipate the impending danger. In the some cases of spatial planning product, the analysis of spatial planning has not significantly accommodated natural disaster information as well as risk analysis and spatial distribution of risk. There were lack of spatial/GIS data support on decision-making (Jumadi et al. 2010).

Spatial planning is defined as the comprehensive, coordinating spatially-oriented planning at all spatial scales from the national level down to the community level, influencing the future distribution and pattern of activities in terms of their locations, transportation, housing, water management, etc. [Fleischhaurer, 2008]. The elements of spatial planning consist of a Spatial Planning Product, Space Use, and Control of Space Use [Undang-undang no. 26 tahun 2007/Act No. 26 of 2007]. Meanwhile, the act stated above reveals that the utilization of space includes any activities carried out by the government, public, and private in the space in accordance with the allotment of the space use that is specified in the plan. Control of space utilization is a preventive measure of deviation from the utilization of existing space to a predetermined plan implemented under the supervision and control. The implementation of control element of spatial planning is the most difficult.

The city spatial plan is included in the General Spatial Plan (RUTR).The plan can be detailed further in the Detail Spatial Plan (RDTR) and the Technical Space Plan (RTR). RUTR planning areas cover the whole administration of the district/city, with the scale of $1: 50,000$ to $1: 100,000$ with the level of accuracy of data and information on the sub-district level or presented in the development unit area (SKP). RDTR planning area includes the area of the development unit (SKP) or parts of one or several SKPs, which cover the range of 10,000-25,000 ha. 
There are several roles of spatial planning in minimizing disaster risk [Fleischhauer, et al., 2005]: (1) To keep a zone from uncontrollable structure development. This is an instrument to keep the zones free from the structure development, especially the ones that are susceptible to flood and landslide. (2) To determine that land use is in line with the intensity and frequency of the threatening danger. For example, farming is allowed in an area susceptible to floods, but settlement is not allowed there. (3) To make recommendation in the plan of land use or zoning. Some recommendations can be made in the planning stages of land use or zoning. (4) To contribute to minimizing the danger potentials. For example, the protection of the susceptible zones to river flooding, preservation, etc. This demonstrates the role that spatial planning can play in mitigating hazards by influencing urban structures and thus can strengthening urban resilience [Fleischhaurer, 2008]. However, there are limits of spatial planning, and therefore an integrated approach is needed that includes variety of authorities to deal with hazards [Fleischhaurer, 2008].

Spatial planning may provide important opportunities to reduce flood impacts, whereas proofing the use of land as well as building positions enhances the reduction capacity of flood impacts. It also said that the risk area in urban areas was caused by rapid population growth occupying any area in the city and mostly in the hazard prone area such as regions around rivers. This is the result of lack of land use regulation by the government that does not match with the rapid urban expansion by the population. It is also due to the failure of urban authorities to regulate building standards, which contributes to the vulnerability of urban populations [ADPC 2013; UNDP 2010]. The condition of settlement is an informal settlement and no hazard-resistant as well as not supported by facilities like schools, public toilet, streets and parks [ADPC, 2013].

The success factor that supported community participation in managing the space and settlement environment on the riparian area for the Case Study in Yogyakarta, Indonesia are the high awareness of community, the role of community leader figures, well targeted program implemented by government, as well as the role of academicians, NGO, and other stakeholder [Rachmawati, 2015]. Area of the case study is now changing, previously unclean settlement area to well-arranged one [Rachmawati, 2015]. The study area is densely populated area that susceptible to flood. One of part of study area also the same riparian with the case in this paper i.e. Code River but in the different location. One of result from another research of Code River area is that Effort to reduce the risk of lahar flood disaster in the Code River settlement can be done by increasing the capacity of communities by creating a resilient and selfsufficient, especially in disaster relief effort in vulnerable areas (Rachmawati, et al., 2014). With the community capacity building, disaster risk reduction is expected to be more efficient, not only speed up recovery conditions at the time of disaster, but as a good capital for anticipated in the future when a disaster occurs (Rachmawati, et al., 2014).

In the case of Vanuatu as a dangerous mountain in the southwest Pacific, community-based planning is required to collate information, policy, and practical risk reduction programs by integrating aspects of traditional aspects such as public knowledge in risk reduction strategies [Cronin, et al., 2004]. For the case of the resettlement program at Mayon Volcano, it must be directed by meaningful consultation with the impacted community who also share in the decision making [Usamah and Haynes. 2011]. Successful resettlement must consider aspects of livelihood security,house design, and the availability of public facilities [Usamah and Haynes, 2011].

Related to research about residents' attitudes and behavior before and after the 2010 Eyjafjallajökull eruptions in southern Iceland, these studies highlighted the difficulties that emergency managers face in developing appropriate response strategies acceptable to vulnerable communities [Bird and Gísladóttir, 2012]. The 2010 Eyjafjallajökull eruptions presented an opportunity tore-assess residents' attitudes and behavior in relationto volcanic risk management in the wake of their firsthandexperiences with volcanic hazards [Bird and Gísladóttir, 2012]. It is important in order to understand that officials' perceptions of risk are now more aligned with those of residents and both recognize the need for more detailed and concise information regarding the impacts offalling ash during and following volcanic eruptions [Bird and Gísladóttir, 2012]. In this regard, the role of communities in managing spacepost-disasters 
needs to be considered in order to achieve a synergy of policies and programs that are launched by the government with local conditions and circumstances.

Related to public perception of the risk of disasters, a national survey in 2012 in Saudi Arabia showed that the majority of the participants conveyed that God is in control of the world and that disasters may be a punishment; however, this does not hinder their desire to be prepared to cope with disasters [Alshehri, et al., 2013]. It also highlighted that direct experience with such disasters does not directly influence perception [Alshehri, et al., 2013].

\section{The Methods}

This research was conducted in Yogyakarta because some parts of the city of Yogyakarta are the areas that are affected by the lahar flood, especially the ones located in the Code River's riparian zone in the sub-district of Danurejan. Secondary and primary data were collected. The secondary data contain the profile of the Sub-district and the results of the city spatial plan of Yogyakarta [the RTRW of the city of Yogyakarta, especially related to the area of Code River in the Sub-district of Danurejan]. The primary data wereobtained by observation,in-depth interviews, and focus group discussions. Observation covers the space use around the area of the Code River in the Sub-district of Danurejan. In-depth interviewsis conducted by interviewing the selected informants. They come from several related offices, like Bappeda (Regional Development Planning Board), Dinas Kimpraswil (Agency for the Regional Settlement and Facilities), and the people living in the affected area.

Focus group discussions were conducted by inviting representatives from the related offices, like Bappeda, Kimpraswil, Sub-district and Kelurahan (the smallest administration in a city), related experts (settlement, city planning, disaster, environment), and local figures. The material for discussion wasrelated to the needs for the space arrangement at the research area. The location of informants in affected areas is shown in Figure 1.

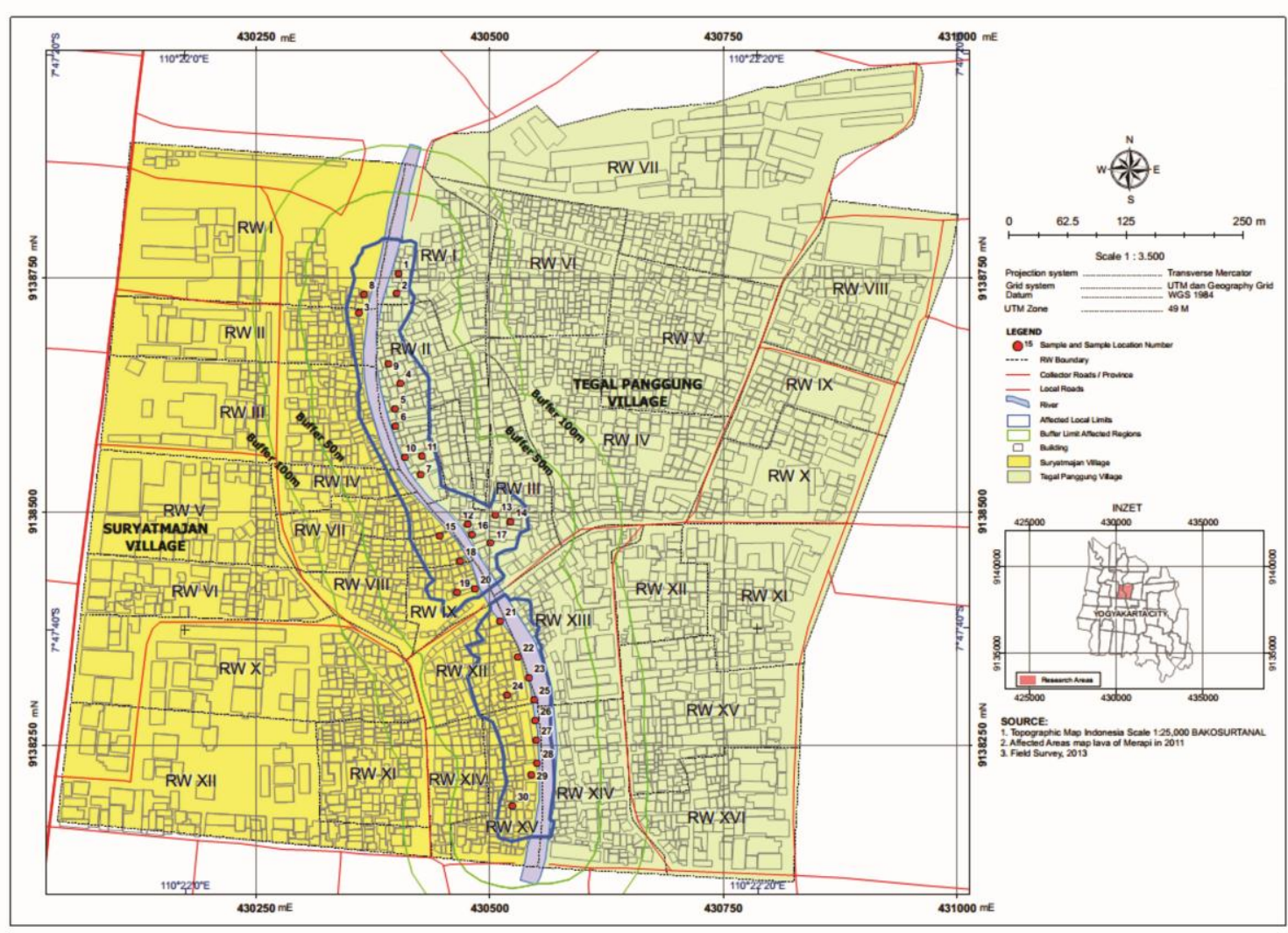

Figure 1. Location Map of Informants in Affected Areas 


\section{Result and Discussion}

In accordance with the spatial plan of the city of Yogyakarta between the years 2010 and 2013, the space pattern for the Sub-district of Danurejan, especially Kelurahan of Suryatmajan, is used for offices, trade and services, tourism, and green open space and the river border. Meanwhile, the Kelurahan of Tegalpanggung is primarily used for settlement and trade and services. The Sub-district of Danurejan belongs to the local main zone of the river border and the buffer zone for nature and culture. The provision and use of the open green zone are directed to preserving and controlling the functions of the area belonging to the river border. This is very important to take into account since the area of Code River is the one susceptible to lahar flooding.

The continuation of this buffer zone for the river border is also supported by the Government Regulation number 38 year 2011 on Rivers. One of the contents of this regulation says that the border line of the river with dikes in city areas must be at least $3 \mathrm{~m}$ from the edge of the dike legs along the river. The area of the Code River's riparian with close distance to the river belongs to the one susceptible to disaster. The houses that are located close to the river are not relevant with the Act of the Government Regulation. Some parts of this area were affected with the Merapi's lahar flood accompanying the rainy season between October 2010 and early 2011. The flood reached the height of $0.5 \mathrm{~m}-1.4 \mathrm{~m}$,and it damaged the settlement area around and along the riparian zone of the river [Rachmawati et al., 2013].

Today, the areas along the border of the Code River and its surroundings have developed into one of the most densely populated areas in the city of Yogyakarta. These areas are inhabited by up to 35.000 people per square kilometer. Meanwhile, the land use for buildings/yards reaches $78 \%$ of the total area (Sub-district of Danurejan Annual Report, 2010). The houses there are built very close to one another, and the houses are very close to the river. They are only separated by narrow paths on both sides that are bordered with dikes. The paths themselves are less than 2 meters wide, as seen in Figures $2 a$ and $2 b$. Figures $3 a$ and $3 b$ shows flooding. Space utilization of the research area is shown by Figure 4 .

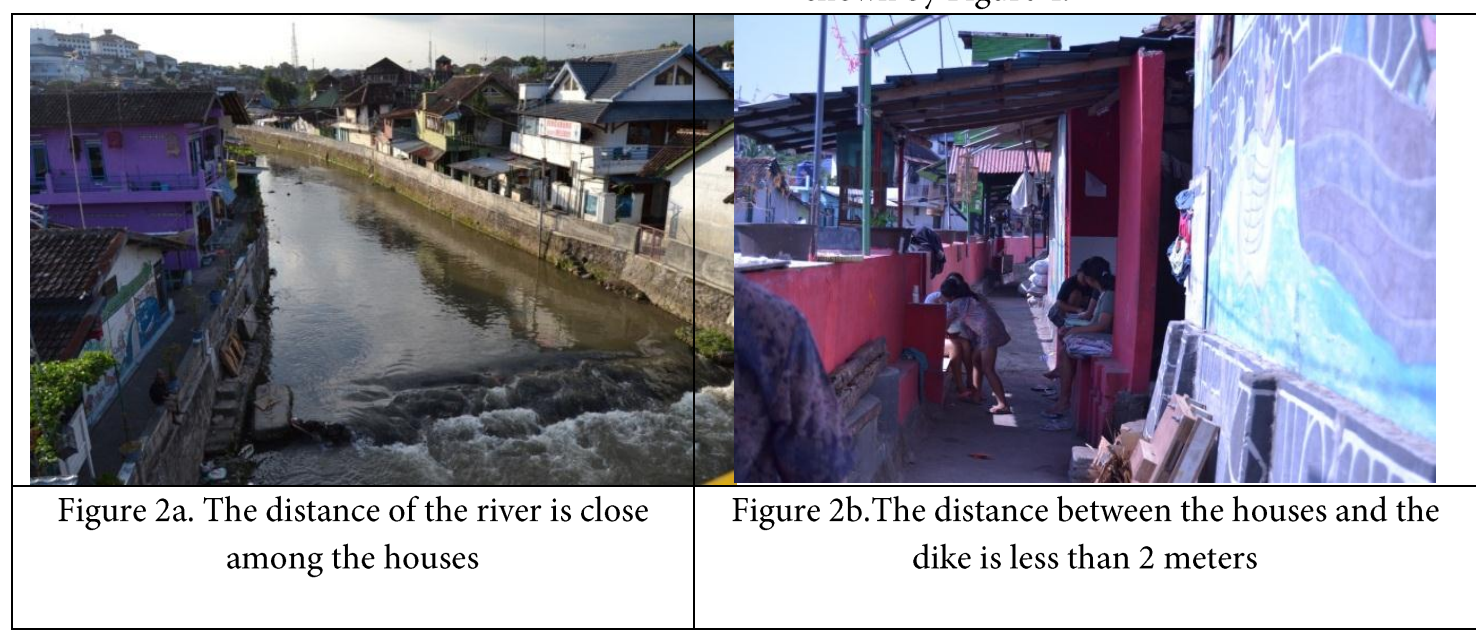




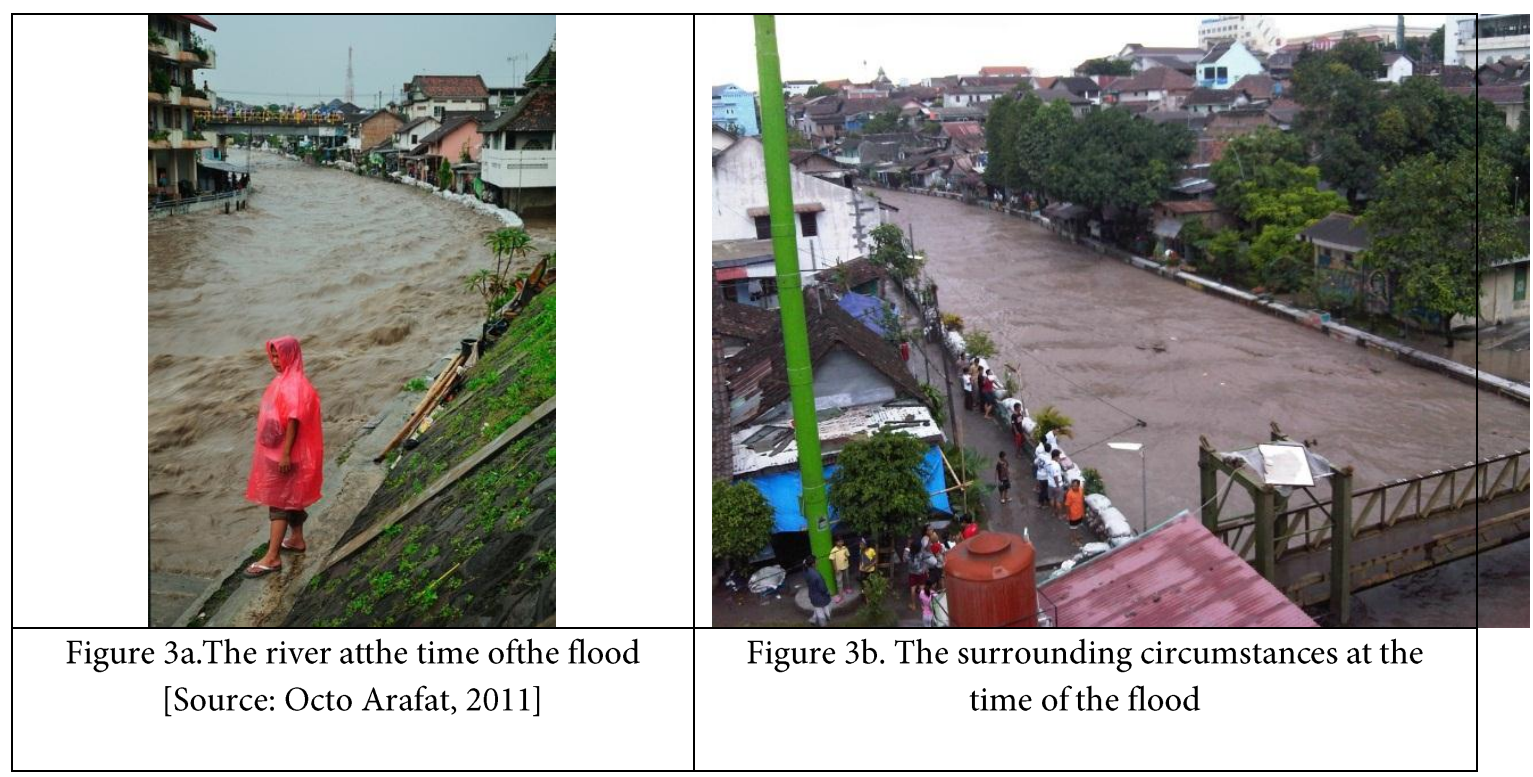

The in-depth interviews demonstrated that most of the people residing in this area are the original people who have been living there since they were born. 21 of the 30 informants had been living in this area for more than 20 years. Most of the settlers in both Kelurahan have already had the certificate of land ownership. The land in several locations is not certified yet because it belongs to wedikenser (sand sedimentation in the river). This land is managed by the government. One of the land uses belonging to wedikenser is for building rusunawa (Rumah Susun Sewa/Several-floor Houses for rent). There are also citizens who make use of wedikenser land for building houses close to the rusunawa, as seen in Figure 5. Three of the 30 informants built their houses on the wedi kenser land. The area belonging to wedi kenser should be a protected area that has been stated on the Government Regulation no. 38 year 2011 on Rivers, stating that the area belonging to the city river border needs to have a dike with the width of 3 meters. In relation to this, most citizens are not well informed about the protected area. However, they are already informed about the area susceptible to disaster. The in-depth interview showed that 16 of 30 informants are already well informed about the area susceptible to disaster.

Most of the informants reveal that they realize that a flood could happen anytime during the rainy season. Yet, they think that it is just a yearly routine. It is difficult for the residents there to decide to move out because they do not have any other place to go. Other reasons are that they have their business activities in the area, their children go to schools nearby, they live close to their workplaces and public facilities, and they feel comfortable in that area. Even though some of the informants have suffered from the same flood 5 times before $(1967,1978,1984,1989,2010)$, they do not feel like moving out for the reasons mentioned above. This is clarified by the FGD results that having no place to move in, feeling comfortable, getting along well among the citizens, and being not too susceptible to disaster have caused them to remain living there. In addition, it is due to their financial status that they cannot afford another house to live in 10 of the 30 informants reveal that they once took part in relocation socializations in 2004 and 2011. The result of the in-depth interview also shows that the transmigration program was once socialized and offered to the flood victims following the last devastating flood. At the beginning, as many as 30 people enlisted themselves to take part in the program. Yet, when conditions became better, only 3 families were still interested in taking part in the program.

Similarly, Razafindrabe, et al. [2012] analyzed flood risk and related impacts to urban communities in central Vietnam. This study aimed to understand flood risks and their impact on a community in order to enhance communities' resilience and adaptive capacity to these threats. Findings showed that social dynamics were apparently strengthened by such disasters, which resulted in cohesion and mutual help following floods in some wards. Also, households with more sources of income and more savings appear to recover faster than others after a flooding event. 
Marrero and Yarnal [2009], through their case study on two flood-prone communities in Puerto Rico, try to put adaptive capacity into the context of people's lives. They reveal that participants perceive floods as one of their risks; however, they find other concerns, i.e., health conditions, family well-being, economic factors, and land tenure, more pressing. The results suggest that addressing these multiple risks and mainstreaming flood management and adaptation into the wider context of people's general well being as well as increasing risk perception will strengthen adaptive capacity for present and future floods [Marrero and Yarnal, 2009].

Keogh, et al. [2011] carried out research in Charleville as a small, in land rural town in Queensland situated on an extensive flood plain, with no significant elevated areas available for relocation. The study aimed to gain an understanding of the vulnerability, resilience, and adaptive capacity of this community by studying the 2008 flood event using structured questionnaires and personal interviews to householders and businesses affected by the 2008 flood and to institutional personnel servicing the region ( $n=91$ ). Results showed that Charleville was found to be staunchly resilient, with high levels of organization and cooperation and well-developed and functioning social and institutional networks. A key finding was that residents believe they have a personal responsibility for preparation and personal mitigation activities, and these activities contribute substantially to Charleville's ability to respond to and cope with flood events [Keogh, et al.
Regarding flood hazard management, the government has adopted a comprehensive operational policy to mitigate flood hazards [Marfai, et al., 2008]. According to Sutardi (2006) and Marfai, et al. [2008], one of the principles of the comprehensive operational policy is to integrate water resources management and flood control measures. Flood control measures shall consist of structural and non-structural measures with special concern to preparedness and self-reliance of the community. Some structural projects have been implemented, including improvement of a dyke system and floodwall to control flooding along the river, especially in the urban-density areas [Marfai and King, 2007d in Marfai, et al., 2008].

In relation to the land use change before and after the lahar flood disaster in the Code Riverbank, is proved by the land use to anticipate and prevent the lahar flood from taking place. They sought to renovate and heighten the dike that directly borders the river. At first, the emergency dike was built by piling sacks filled with sand on top of each other. After the disaster, the government and local citizens began to build a permanent dike with a height of $1.2-2$ meters. This dike heightening affected the space use, i.e., the wall of the dike became higher. Unsurprisingly, currently the local citizens use it as a public space. They like to sit on it to meet and talk to one another and to do other activities. Meanwhile, in relation to the houses, renovating houses and building dikes in front of the house doors are aimed at preventing floods from entering the houses.

2011].

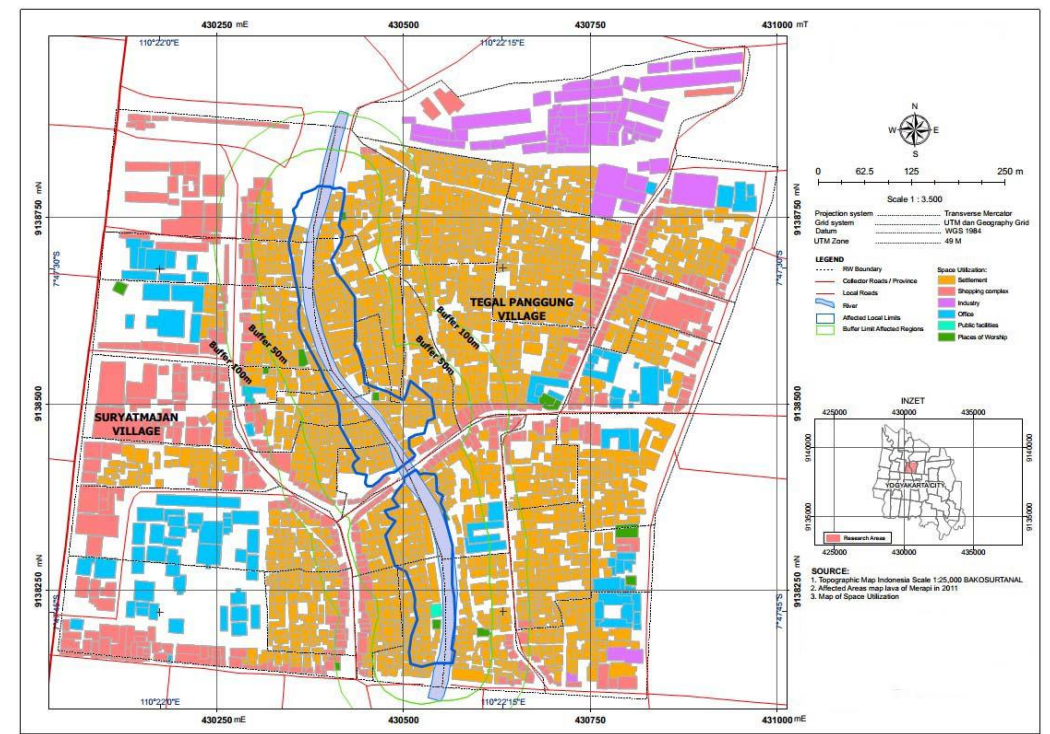

Figure 4. Map of Space Utilization of the Area Affected by Lahar Flood in 2011 


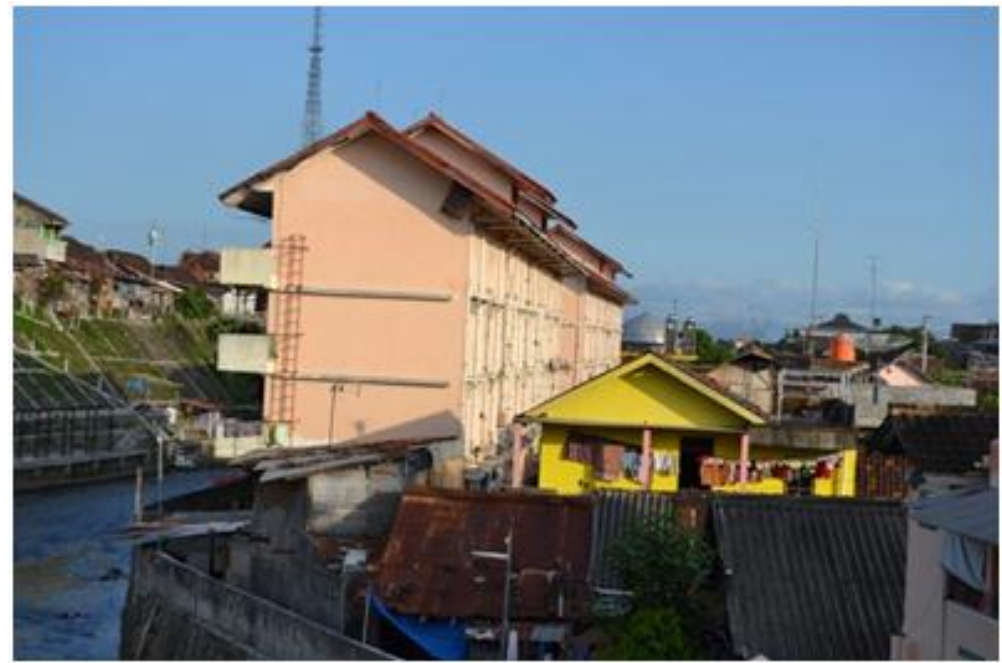

Figure 5. Rusunawa (Vertical Units of Houses for Rent)

\section{The Need for Spatial Planning}

Urbanization often increases the exposure of people and economic assets to hazards. Cities are usually the economic drivers within their countries and the centers of intellectual, political, business, and financial activities. Creating new patterns of risk management from disasters in urban areas is particularly a complex plan [ADPC, 2013]. It is also said that risk in urban areas is further exacerbated by the rapid population growth occupying any area in the city and mostly in the hazard prone area such as lands around rivers. This is the result of lack of land use regulation by the government that doesnot match with the rapid urban expansion by the population and the failure of urban authorities to regulate building standards and contribute to the vulnerability of urban populations. [ADPC, 2013; UNDP, 2010]

One of the urban management functions is to create master planning, land use planning, urban planning, environmental policies and plans for urban parks, and construction policies including building safety standards. Urban management is the government's responsibility at any level of management. Yet, the government cannot effectively manage disasters if they lack an understanding of both institutional understanding and potential impact of hazards that threaten the local population, infrastructure, and economy. [UNDP, 2010]

Sapountzaki, et al. [2011] addresses the problem of lack of coordination between policies and actors with joint competence for risk management, i.e., civil protection, spatial planning, and sectoral planning. He asserted that spatial planning in particular is assigned a minor (or no role at all), though it might perfectly operate as the coordinating policy platform; the reason for this is that spatially relevant analysis and policy guidance is an omnipresent component of the risk management cycle.

It is necessary for the government and local citizens to pay attention to the spatial planning of the affected flood plain of Code River. The existing data show that $78 \%$ of it is used for housing [the Sub-district of Danurejan in Annual Report, 2010]. This percentage shows that it is necessary to add the space function for public space or open green space in the area, considering that this area is a protectedzone of the river border and is susceptible to lahar flooding.

Results from the in-depth interview show that the need of spatial planning in the area of Code River's flood plain is mostly for the development of open green areas both along the river and in several other areas. The other needs of spatial planning are renovating the dike, deepening the river, improving environment [e.g., widening the path, water absorption, and drainage], improving water pipe and well installation, improving and developing restrooms, and other supporting facilities like building a floodgate, electricity network, crossing bridge, mosque, facility for PAUD (child education for the very early learners), and rusunawa.

The result of FGD shows several alternatives for handling the situation. In relation to the need of spatial planning, it is necessary for the flood plain of Code River to be designed with the spatial planning that makes the area resistant to disaster, as presented below: 
"In the future, it is expected that there will be a synergy among the stakeholders and the citizens of the local area. The area of Code River may become the Disaster-Resistant Area in relation to Indonesia as a country of disaster tourism" (Source of information: representative from Settlement and Region Infrastructure Agency)

In relation to the densely-populated area located in an area susceptible to disaster, it is necessary for the appropriate accessibility to be improved, for example widening the path on both sides of the river's flood plain. This is very important for evacuation during the emergency condition if a disaster occurs. In addition, the widened path is also useful for ecotourism and provides open green space and space for public interaction. In addition to accessibility, the spatial planning of the settlement needs to be designed in accordance with the regulation, mainly, the area belonging to the river border should be 3 meters away from the outer sides of the river. Here are several statements from the informants:

"It is necessary to have a wider path mainly on the flood plain of Code River for easy evacuation when a big flood happens during eruption" (Source of information: Community leader, the Kelurahan of Suryatmajan).

...widening the path on both sides of the river and giving incentives to the citizens whose land is used for path widening. Widening the road as well as efforts to increase accessibility for ecotourism and when occuri emergency unconditionally." (Source of information: member of expert planning association)

"It is necessary to build dike to anticipate the flood flowing into the area. Dredging the river more deeply needs to be done to enable the water to flow more smoothly." (Source of information: representative from Kelurahan Suryatmajan)

In addition to the proposal of spatial planning, FGD also results in several proposals in relation to the action plans ofthe flood plain of Code River, particularly the one located in the Kelurahans of Suryatmajan and Tegalpanggung. It begins with the grand design of the flood plain of Code River so that the spatial planning can be implemented thoroughly and on target. So far, the spatial planning has not been well synergized by both the government and the local citizens. In the future, there will be aneed forspatial planning that is synergized in order to achieve better results. An informant is quoted as saying:

"The most important point is that the grand design reflects the planning for buildings and environment that is participatorily made" [information source: the head of Sub-district of Danurejan]

FGD also results in several alternatives for spatial planning. They are urban renewal, building rusunawa / rusunami, and relocation. These three alternatives for spatial planning are adaptable with the existing need of spatial planning for the area. The first stage of urban renewal can be implemented for the case of Code River's flood plain. So far, what has been implemented on this stage is already in accordance with the spatial planning (e.g., widening the path on both sides of the river, establishing an open green area for public space, and other activities). An informant is quoted as saying:

"By having wider surface of the dike and also wider distance between houses and the dike, it is possible to use the area for foodstalls (culinary trip). Equipped with good lighting, it could attract visitors to have a culinary trip there in the evening" (Source of information: representative from Kelurahan Suryatmajan)

"The dike needs to be build sturdily, and the houses close to the sides of the river need structuring, if necessary, need to be relocated. Thus, the area along and around the sides of the river can be made tourist destination" [Source of information: representative from Kelurahan Tegalpanggung].

The second stage is to build vertical public housing. It can be Rusunawa [Rumah Susun Sederhana Sewa / Vertical Units of Houses for Rent] and Rusunami [Rumah Susun Sederhana Milik / Vertical Units of Houses for Posession Right]. Meanwhile, the third stage is relocation. However, relocation should be the last option due to its complexity for implementation. The agreement from those who need to be relocated has to be made since they have to adapt themselves in a new place. 


\section{Spatial Planning in the Disaster Area: Several Considerations}

In relation to the spatial planning in the flood plain of Code River, it is necessary to care for susceptible groups. There should be a gathering point and evacuation lane so that the susceptible groups find it easy to evacuate in case of adisaster. Despite the fact that there is no clear definition about who belongs to the susceptible groups, the law and policy on Disaster Risk Management focusing on the floods that have occurred in Japan and the USA covers several groups of susceptible society. They are, for example, the elderly, children, and handicapped persons. Meanwhile, the Canadian Government adds to the susceptible society by including pregnant women, blind people, and pet owners [Vink and Takeuchi, 2013]. The national guidelines to which the determination of susceptibilities are referred will be different from one place to another. Therefore, there should be coherence with otherlaws affecting the main cause of susceptibilities [Vink and Takeuchi, 2013].

In the case of housing along the flood plain of Code River, the development of a new dike higher than the previous one is an example of real action tomake space safe and comfortable, mainly for the kids and elderly. This space utilization is an effort to care for the susceptible groups.

It is also necessary for further space utilization to notice the factors of lahar flooding and risks, considering that the lahar flood in the area could happen again and again due to the risks of periodical eruption of Mount Merapi. Therefore, it is important to notice the distance between the houses and river.In addition, the kinds of buildings also need to be taken into consideration. The risk analysis of the case of Gletser that covers the active volcano Nevado del Tolima, Central CordilleraColombia, is very useful to prevent any effective disaster. This is based on the lahar evaluation, the danger scenario of related rain flood, and different aspects of susceptibilities [Ku“nzler, et al., 2012]. The methodology applied is based on the variables of the number of population (how many inhabitants there are), lahar scenario (the volume is based on the ice melting), flood model (flood design of the periods of 10 and 100 years), and susceptibilities (considering the physical susceptibility of settlement and population density) [Ku"nzler, et al., 2012]. Meanwhile, social susceptibility is revealed by the structures of the inhabitant ages and poverty [Ku"nzler, et al., 2012]. According to Ku"nzler, et al. [2012], such a methodology has proven to be an appropriate tool to describe the spatial distribution of risk. Both local and regional authorities consider it useful for minimizing disaster risks, harmonizing the risk analysis of technology-techniques, and approaching the social sciences to be the refererence of general concept that needs further development. For this reason, it is necessary to integrate the study on risk analysis and thespatial distribution of risk in the area of Code River's flood plain into the detailed spatial plan of the area. Therefore, this will become the considerations in mapping the protecting zones and planning the settlement development.

The application of spatial techniques and innovative statistics involving many sectors as the basis analysis plays a very important role in formulating indicators and accurate and firm targets for monitoring the impacts of spatial plans [Plessis, 2013 and Todes, 2008 in Plessis, 2013]. In this case, for the last decade, the existence of modern computation technology has changed methods of analysis, city modeling, spatial techniques, and statistics that must solve all the three dimensions of cities, including formations and functions like density, diversity, and spatial patterns [Plessis, 2013]. Based on studies of three cases of European (regional and local) countries regarding risk management, Sapountzaki [2011] gave suggestions related to disconnected, riskrelevant policies turning a blind eye to spatial planning. They suggest that this might cause several adverse repercussions, i.e., breaks in the responsepreparedness-prevention-remediation chain [which should function as a continuum], minimal attention to prevention, risk expansion and growth instead of mitigation, lack of synergies between involved actors as well as duplicated or even diverging measures and funding. The above statements and the results of this study reinforce the need forspatial planning that give sattention to disaster information and disaster risk.

\section{Conclusion}

The space available on the flood plain of Code River is mostly used for housing. Some houses are exactly located on the protectedzone of the river's flood plain. Flooding that has taken place several times has not spurred the local citizens to move to a 
safe area. Also, it does not make the government force the policy of relocation for the flood victims.

The changes of space use are so far aimed at minimizing the disaster impact by heightening the dike, adding home-protecting building to prevent water from entering the area, widening paths, and establishing open green space in the affected area.

In the future, the citizens residing in the flood plain of Code River are in need of space structuring that will help to make the area resistant to disaster. In addition, the improvement of accessibility to anticipate any emergency for evacuation when a disaster happens needs to be realized. At last, an open green space for public interaction and environmental care needs to built.

In relation to an effort to increase economic activities based on the environment, the local citizens believe that ecotourism constitutes an appropriate plan. Therefore, thisneeds to be supported with the action plan of flood plain structuring of Code River. There should be a grand design in order that the structuring can be implemented thoroughly. The making of this grand design is expected to be a synergy between the Provincial and Kelurahan Governments that also involve the local citizens. Urban renewal is offered as the alternative of spatial planning in the form of building rusunawa and rusunami as public housing that is built vertically. Meanwhile, relocation is considered the last alternative.

Several points that still need to be considered in the space structuring in the area susceptible to disaster are based on the need for susceptible groups, risk analysis integration and the spatial distribution of risk into a detailed spatial plan. The application of spatial techniques, innovative statistics, and inter sectors with the support of modern computation technology [information and communication technology] will greatly benefit spatial plan development and plan monitoring.

\section{Acknowledgement}

The authors wish to thank the Faculty of Geography, Universitas Gadjah Mada, for supporting this research through the Hibah Penelitian Dosen 2013. Thanks to the Institute for Research and Community Service, Universitas Gadjah Mada for financial support in publishing this research result through Insentif Publikasi Karya Ilmiah dalam Jurnal Internasional 2014.
Thanks to Dr. Danang Sri Hadmoko, M.Sc. who reviewed this article.

\section{References}

ADPC. (2013). Integrating Disaster Risk Management into Urban Management, Disaster Risk Management Practitioner's Handbook Series, Bangkok.

Alshehri, S.A., Rezgui, Y. \& Li, H. (2013). Public Perception of The Risk of Disasters in a Developing Economy: The Case of Saudi Arabia.. Nat Hazards (2013) 65: 1813. doi:10.1007/s11069-012-0445-5

Bird, D.K. and Gísladóttir, G. (2012). Residents' attitudes and behaviour before and after the 2010 Eyjafjallajökull eruptions-a case study from southern Iceland. Bulletin Volcanology. 74:1263-1279, DOI 10.1007/s00445-012-0595zSpringer-Verlag 2012.

Cronin, S.J., Gaylord, D.R., Charley, D., Alloway, B.V., Wallez, S., Esau, J.W. (2004). Participatory Methods Of Incorporating Scientific With Traditional Knowledge For Volcanic Hazard Management On Ambae Island, Vanuatu. Bulletin Volcanology. 66:652-668 DOI 10.1007/s00445-004-0347-9.

Damiania, M.L., Groppellib, G., Norinic, E. Bertinoa, A. Gigliutoc, A. Nucitaa. (2006). A Lava Flow Simulation Model For The Development of Volcanic Hazard Maps For Mount Etna (Italy). Computers \& Geosciences. 32: 512-526. Elsevier.

Fleischhauer, Greiving, Wanczura. (2005). Spatial Planning in The Focus of Hazard and Risk Assessment/Management in Europe. EURORIOB Conference Wroclaw 19 - 21 X 2005 Exchange of experiences connected with flood prevention.

Fleischhaurer, M. (2008) The Role of Spatial Planning in the Strengthening Urban Resilience, H.J. Pasman and I.A. Kirillov (eds.), Resilience of Cities to Terrorist and other Threats, Springer Science + Business Media B.V Jean-Claude Thouret, J.C., 1999, Urban hazards and risks; consequences of earthquakes and volcanic eruptions: an introduction. GeoJournal. 49: 131-135, 1999. (C) 2000 Kluwer Academic Publishers, Printed in the Netherlands.

Heryanti, D.N. and Kingma, Nanette C. (2012). Community Based Approach to Assess Flood 
Risk Perceptiin Along Code River. Indonesian Journal of Geography. 44 (2), 134-149.

Jumadi, R. Suharyadi, Arbind M. Tuladhar. (2010). Web-Based Spatial Information System to Support Collaborative Lahars Disaster Management. Indonesian Journal of Geography. 44 (1), 87-103.

Keogh, D.U, Armando Apan, Shahbaz Mushtaq, David King, Melanie Thomas. (2011). Resilience, vulnerability and adaptive capacity of an inland rural town prone to flooding: a climate change adaptation case study of Charleville, Queensland, Australia, Natural Hazards. 59:699-723, DOI 10.1007/s11069-0119791-y Springer Science+Business Media B.V. 2011.

Künzler,Matthias; Huggel, Christian and Ramı'rez, Juan Manuel. (2012). A risk analysis for floods and lahars: case study in the Cordillera Central of Colombia, Received: 26 February 2010/ Accepted: 23 June 2012/ Published online: 31 July 2012. Springer Science+Business Media B.V.

Lavigne, Franck. (1999). Lahar hazard microzonation and risk assessment in Yogyakarta city, Indonesia, GeoJournal. 49: 173-183. (c) 2000 Kluwer Academic Publishers. Printed in the Netherlands.

Marfai, M.A., King, L., Singh, L.P., Mardiatno, J., Sartohadi, J., Hadmoko, D.S., Dewi, A. (2008). Natural hazards in Central Java Province, Indonesia: an overview. Environ Geol (2008) 56:335-351. DOI 10.1007/s00254-007-1169-9. Springer-Verlag 2008.

Marrero, T.L. and Brent Yarnal, 2009, Putting adaptive capacity into the context of people's lives: a case study of two flood-prone communities in Puerto Rico, Natural Hazards (2010) 52:277-297 DOI 10.1007/s11069-0099370-7 Springer Science+Business Media B.V.

Pareschi, M. T., L. Cavarra, M. Favalli, F. Giannini And A. Meriggi. (1999). GIS and Volcanic Risk Management. Natural Hazards, 21: 361-379, 2000.@ 2000 luwer Academic Publishers, Printed in the Netherlands.CSGSDA-CNR, via S, Maria 53, I-56100 Pisa, Italy.

Plessis, D. J. du. (2013). A Critical Reflection on Urban Spatial Planning Practices and Outcomes in Post-Apartheid South Africa, Published online: 27 July 2013, Springer Science+Business Media Dordrecht 2013, Urban Forum (2014) 25:69-88, DOI 10.1007/s12132-013-9201-5
Putra, T.Y.D, Aditya, Walter de Vries, T. (2011). A Local Spatial Data Infrastructure To Support The Merapi Volcanic Risk Management: A Case Study at Sleman Regency, Indonesia. Indonesian Journal of Geography. 43 (1) June 2011, 25 - 48, ISSN 0024-9521.

Rachmawati, R. (2015). Community Participation in Managing The Space and Settlement Environment on the Riparian Area: A Case Study in Yogyakarta Indonesia, KKU International Journal of Humanities and Social Sciences. 5 (1), January-April 2015, ISSN 23509767.

Rachmawati, R., Edi Sukoco, Tri Budiharto. (2014). Penataan Ruang dan Kapasitas Masyarakat untuk Pengurangan Risiko Bencana: Kajian di Kawasan Bantaran Sungai Code Kota Yogyakarta. Prosiding Seminar ASPI 2014, Mengembangkan Kota dan Wilayah yang Tangguh dan Berkelanjutan, Program Perencanaan Wilayah dan Kota, Fakultas Teknik, Universitas Islam Riau, Pekanbaru, Riau. ISBN: 978-979-3793-65-8

Razafindrabe, B.H. N., Ryohei Kada, Makoto Arima, Shoji Inoue. (2012). Analyzing flood risk and related impacts to urban communities in central Vietnam. Springer Science+Business Media Dordrecht .

Sapountzaki, K., Sylvia Wanczura, Gabriella Casertano, Stefan Greiving, Gavriil Xanthopoulos, Floriana F, Ferrara. (2011). Disconnected policies and actors and the missing role of spatial planning throughout the risk management cycle, Natural Hazards (2011) 59:1445-1474 DOI 10.1007/s11069-011-9843-3. Springer Science+Business Media B.V.

Thouret, J.C. (1999). Urban hazards and risks; consequences of earthquakes and volcanic eruptions: an introduction, GeoJournal, 49:131135, 1999. (C)2000 Kluwer Academic Publisher, Printed in the Netherands.

Undang-undang no. 26 tahun 2007 tentang Penataan Ruang / Spatial Planning Act. Number 26 year 2007.

UNDP. (2010). Urban Risk Management, Bureau for Crisis Prevention and Recovery.

Usamah, M. and Haynes, K. (2011). An Examination Of The Resettlement Program At Mayon Volcano: What Can We Learn For Sustainable Volcanic Risk Reduction. Bulletin 
Volcanology. 74:839-859, DOI 10.1007/s00445011-0567-8, Springer-Verlag 2011

Vink, Karina and Takeuchi, Kuniyoshi. (2013). International Comparison Of Measures Taken For Vulnerable People In Disaster Risk Management Laws, International Journal of Disaster Risk Reduction. 4 (2013) 63-70.

Yulianto, F., Sofan, P., Khomarudin, M.R., Haidar M. (2012). Extracting The Damaging Effects Of
The 2010 Eruption Of Merapi Volcano In Central Java, Indonesia, Natural Hazards (2013), 66:229-247 DOI 10.1007/s11069-0120438-4, Springer Science+Business Media Dordrecht 2012. 